\title{
HUBUNGAN PERAN KELUARGA DALAM MERAWAT LANSIA DENGAN TINGKAT DEPRESI LANSIA DI WILAYAH KERJA PUSKESMAS KUMUN
}

\author{
Azma Ulia ${ }^{1}$ \\ Akademi keperawatan Bina Insani Sakti Sungai Penuh ${ }^{1}$ \\ Email: azmaulia6@gmail.com
}

\begin{abstract}
Lack of family role in caring elderly with depression level of elderly marked by still many elderly who less get care from family. The purpose of this study was to determine the role of the family in caring for the elderly against the level of elderly depression in the work area of Kumun Public Health Center in 2015. This type of research is descriptive analytics using Cross Sectional approach. The population in this study were all Elderly who experienced Depression in Working Area of Public Health Center of Kumun with number of 105 people. The sample in this research is 60 respondents. Sampling is done by Accidental Sampling method by taking case or respondent that happened to exist or available somewhere in accordance with research context. The data were collected by using questionnaires and guided interviews in August 2018. The data analysis technique used in this research is Spearman Rank correlation test with 95\% confidence degree $(\alpha=0,05)$. The results showed that Odd Ratio $(\mathrm{OR})=6.732$ with $\mathrm{P}$ value $=0,005$ where $\mathrm{p}<0,05$ then $\mathrm{H}_{0}$ rejected and $\mathrm{H}_{1}$ accepted which means that there is a significant relationship between the level of elderly depression with the role of family in caring elderly in the working area of Public Health Center of Kumun. This research is expected to serve as input for Public Health Center to improve nursing service of soul and family to give role and support in elderly care to prevent relapse of depression client.
\end{abstract}

\section{Keywords: Family Role, Depression}

\begin{abstract}
ABSTRAK
Kurangnya peran keluarga dalam merawat lansia dengan tingkat depresi lansia ditandai dengan masih banyaknya lansia yang kurang mendapatkan perawatan dari keluarga. Tujuan dari penelitian ini adalah untuk mengetahui peran keluarga dalam merawat lansia terhadap tingkat depresi lansia di Wilayah kerja Puskesmas Kumun Tahun 2018. Jenis penelitian ini adalah deskriptif analitik dengan menggunakan pendekatan cross sectional. Populasi dalam penelitian ini adalah semua Lansia yang mengalami Depresi di Wilayah Kerja Puskesmas Kumun dengan jumlah sebanyak 105 orang. Sampel dalam penelitian ini berjumlah 60 orang responden. Pengambilan sampel dilakukan dengan metode Accidental Sampling yaitu dengan cara pengambilan kasus atau responden yang kebetulan ada atau tersedia di suatu tempat sesuai dengan konteks penelitian. Pengambilan data dilakukan dengan menggunakan kuesioner dan wawancara terpimpin pada bulan Agustus 2018. Teknik analisa data yang digunakan pada penelitian ini
\end{abstract}


adalah uji korelasi spearman rank dengan derajat kepercayaan $95 \%(\alpha=0,05)$. Hasil penelitian menunjukkan bahwa Odd Ratio $(\mathrm{OR})=6,732$ dengan nilai $p$ value $=0,005$ dimana $\mathrm{p}<0,05$ maka $\mathrm{H}_{0}$ ditolak dan $\mathrm{H}_{1}$ diterima yang artinya bahwa terdapat hubungan yang signifikan antara tingkat depresi lansia dengan peran keluarga dalam merawat lansia di wilayah kerja Puskesmas Kumun. Penelitian ini diharapkan dapat dijadikan sebagai masukan bagi Puskesmas untuk meningkatkan pelayanan keperawatan jiwa dan keluarga memberikan peran dan dukungan dalam perawatan lansia untuk mencegah kekambuhan klien depresi.

Kata Kunci : Peran Keluarga, Depresi 


\section{PENDAHULUAN}

Lanjut usia merupakan proses menua pada manusia yang tidak dapat dihindarkan. Salah satu tanda penurunan fungsi tubuh untuk beradaptasi dengan stress lingkungan dan merupakan tahap akhir dari siklus kehidupan manusia, sering ditandai dengan kondisi kehidupan yang tidak sesuai dengan yang diharapkan. Hal ini merupakan beban berat bagi lansia yang dapat menimbulkan depresi (Depsos, 2006 dalam Kristyaningsih, 2011). Kurangnya peran keluarga kepada lanjut usia, akan mempengaruhi koping pada lansia tidak adekuat. Koping yang tidak adekuat dalam menghadapi masalah, akan menyebabkan krisis yang bertumpuk dan berkepanjangan yang akhirnya dapat menimbulkan depresi.

World Health Organization (WHO) menetapkan depresi pada lansia di seluruh dunia diperkirakan ada 500 juta jiwa dengan usia rata-rata 60 tahun. Pada tahun 2000 jumlah lanjut usia di Indonesia terdapat 22,3 juta jiwa dengan umur harapan hidup 65 - 75 tahun. Pada tahun 2020 akan meningkat menjadi 11,09\% (29,12 juta lebih) dengan usia harapan hidup 70-75 tahun dan diperkirakan pada tahun 2025 akan mencapai 1,2 milyar (Nugroho, 2000 dalam Kristyaningsih, 2011).

Peran keluarga adalah keberatan, kesedihan, kepedulian dari orang-orang yang dapat diandalkan, menghargai dan menyayangi kita, pandangan yang sama juga dikemukakan oleh Cobb (2002), mendefinisikan peran keluarga sebagai adanya kenyamanan, perhatian, penghargaan atau menolong orang dengan sikap menerima kondisinya, peran keluarga tersebut diperoleh dari individu kelompok, peran keluarga sangat dibutuhkan dalam merawat lansia terhadap tingkat depresi, adanya peran keluarga terhadap lansia ini juga dapat mengurangi beban lansia dan juga dapat mengurangi kejadian depresi pada lanjut usia.

Depresi merupakan satu masa terganggunya fungsi manusia yang berkaitan dengan alam perasaan yang sedih dan gejala penyertainya, termasuk perubahan pada pola tidur dan nafsu makan, psikomotor, konsentrasi, anhedonia, kelelahan, rasa putus asa, dan tidak berdaya serta bunuh diri. Depresi bisa menjadi masalah yang kronik dan berulang yang menyebabkan seseorang tidak mampu untuk mengurus diri sendiri, selain itu depresi dapat menjurus kepada tindakan bunuh diri (Dani, 2012 dalam Nisa', 2014). 
Depresi pada lansia dapat dipengaruhi oleh berbagai faktor, antara lain penurunan fungsi dari organ tubuh, kehilangan sumber nafkah, perubahan gaya hidup dan sebagainya. Stress sangat rentan terjadi pada lanjut usia karena faktor kehilangan, penurunan kesehatan fisik, dan kurangnya dukungan dari keluarga (Kristiyaningsih, 2011).

Di wilayah kerja Puskesmas Kumun didapatkan data penyakit gangguan campuran anxietas dan depresi, persentase pada tahun 2016 sebanyak 98, dan pada tahun 2017 sebanyak 110. Pada survey awal yang dilakukan oleh peneliti pada tanggal 5 Januari 2018 jam 10.00 WIB yang dilakukan di Puskesmas Kumun, dari hasil wawancara pada penelitian pendahuluan yang dilakukan pada 10 orang lansia menujukkan bahwa 4 orang mengatakan sering sedih tanpa 336las an dan 6 orang mengatakan terus menerus mengalami perasaan terpuruk.

\section{METODE}

Jenis penelitian ini adalah deskriptif analitik dengan menggunakan pendekatan cross sectional dimana data pada variabel independen (peran keluarga) dan variabel dependen (tingkat depresi lansia) dikumpulkan dalam waktu yang bersamaan (Notoatmodjo, 2012 ).

Populasi dalam penelitian ini adalah semua Lansia yang mengalami Depresi di Wilayah Kerja Puskesmas Kumun dengan jumlah sebanyak 105 orang.

Sampel diambil dengan metode Accidental Sampling yaitu dengan cara pengambilan kasus atau responden yang kebetulan ada atau tersedia di suatu tempat sesuai dengan konteks penelitian (Sastroasmoro, 2011). Penghitungan sampel berdasarkan rumus Lameshow dan perhitungannya sebagai berikut:

$$
\begin{aligned}
\mathrm{n} & =\frac{\mathrm{N} \cdot \mathrm{Z}^{2} 1-\mathrm{x} / 2 \cdot \mathrm{P}(1-\mathrm{P})}{(\mathrm{N}-1) \cdot \mathrm{d}^{2}+\mathrm{Z}^{2} 1-\mathrm{x} / 2 \cdot \mathrm{P}(1-\mathrm{P})} \\
& =\frac{105 \cdot 1,96 \cdot 0,5(1-0,5)}{(105-1) \cdot 0,05+1,96 \cdot 0,5(1-0,5)} \\
\mathrm{n} & =60 \text { orang } .
\end{aligned}
$$

Jadi, Jumlah sampel pada penelitian ini sebanyak 60 orang.

Keterangan :

$$
\begin{aligned}
& n=\text { besar sampel } \\
& \mathrm{Z}^{2} 1-\mathrm{x} / 2=1,96 \\
& \mathrm{P}=\text { perkiraan proporsi } 50 \%
\end{aligned}
$$




$$
\begin{aligned}
& \mathrm{N}=\text { Jumlah Populasi } \\
& \mathrm{d}=\text { tingkat kepercayaan (presisi 5\%) }
\end{aligned}
$$

Penelitian ini dilakukan pada bulan Februari di Puskesmas Jujun.

\section{HASIL PENELITIAN}

\section{Analisa Univariat}

\section{Peran Keluarga}

Tabel 4.2

Distribusi Frekuensi Peran Keluarga Klien

\begin{tabular}{|c|c|c|}
\hline Peran Keluarga & $\mathbf{F}$ & $\%$ \\
\hline Kurang Baik & 33 & 55,0 \\
\hline Baik & 27 & 45,0 \\
\hline Jumlah & 60 & $100 \%$ \\
\hline
\end{tabular}
di Wilayah Kerja Puskesmas Kumun Tahun 2018

Berdasarkan tabel 4.2 diperoleh data bahwa lebih dari separoh peran keluarga kurang baik dalam merawat lansia tingkat depresi dengan jumlah 33 orang $(55,0 \%)$.

\section{Tingkat Depresi}

\section{Tabel 4.3}

Distribusi Frekuensi Tingkat Depresi Lansia

\begin{tabular}{|c|c|c|}
\hline Tingkat Depresi & $\mathbf{F}$ & $\%$ \\
\hline Berat & 43 & 71,7 \\
\hline Ringan & 17 & 28,3 \\
\hline Jumlah & 60 & $100 \%$ \\
\hline
\end{tabular}
di wilayah kerja Puskesmas Kumun Tahun 2018

Berdasarkan tabel 4.3 dapat diperoleh data bahwa lebih dari separoh tingkat depresi lansia di wilayah kerja Puskesmas Kumun Tahun 2018 mengalami tingkat depresi berat dengan jumlah 43 orang $(71,7 \%)$ 


\title{
Analisa Bivariat
}

\section{Hubungan Peran Keluarga dalam Merawat Lansia dengan Tingkat Depresi Lansia}

\author{
Tabel 4.4
}

Distribusi Frekuensi Hubungan Peran Keluarga dalam Merawat Lansia dengan Tingkat Depresi Lansia di Wilayah Kerja Puskesmas Kumun Tahun 2018 $(\mathbf{n}=60)$

\begin{tabular}{|c|c|c|c|c|c|c|c|c|}
\hline \multirow{3}{*}{$\begin{array}{l}\text { Tingkat } \\
\text { Depresi }\end{array}$} & \multicolumn{4}{|c|}{ Peran Keluarga } & \multirow{2}{*}{\multicolumn{2}{|c|}{ Total }} & \multirow{3}{*}{ P Value } & \multirow[b]{2}{*}{ OR } \\
\hline & \multicolumn{2}{|c|}{$\begin{array}{c}\text { Kurang } \\
\text { Baik }\end{array}$} & \multicolumn{2}{|c|}{ Baik } & & & & \\
\hline & $\mathbf{F}$ & $\%$ & $\mathbf{F}$ & $\%$ & $\mathbf{F}$ & $\%$ & & \\
\hline Berat & 29 & 67,44 & 14 & 32,56 & 43 & 100 & 0,005 & 6,732 \\
\hline Ringan & 4 & 23,53 & 13 & 76,47 & 17 & 100 & & \\
\hline
\end{tabular}

Berdasarkan tabel 4.4 Hasil analisa hubungan antara peran keluarga dalam merawat lansia dengan tingkat depresi lansia di wilayah kerja Puskesmas Kumun tahun 2018 diperoleh bahwa peran keluarga yang kurang baik dengan tingkat depresi berat lebih tinggi dengan jumlah responden 29 orang $(67,44 \%)$, peran keluarga kurang baik pada tingkat depresi ringan dengan jumlah responden 4 orang $(23,53 \%)$ dan peran keluarga baik dalam merawat lansia pada tingkat depresi berat dengan jumlah responden 14 orang (32,56\%) sedangkan peran keluarga pada tingkat depresi ringan dengan jumlah responden $13(76,47 \%)$.

Untuk mengetahui hubungan antara peran keluarga dengan tingkat depresi peneliti menggunakan uji spearman rank yang menunjukkan nilai koefesien korelasi dengan nilai Odd Ratio $(\mathrm{OR})=6,732$ dengan nilai $\mathrm{P}$ value $=0.005$ dimana $\mathrm{p}<0,05$ maka $\mathrm{H}_{0}$ ditolak dan $\mathrm{H}_{1}$ diterima yang artinya bahwa terdapat hubungan yang signifikan antara tingkat depresi lansia dengan peran keluarga dalam merawat lansia di wilayah kerja Puskesmas Kumun artinya semakin tinggi peran keluarga dalam merawat lansia semakin rendah tingkat depresi pada lansia.

\section{PEMBAHASAN}

\section{Tingkat Depresi pada Lansia}

Berdasarkan data yang diperoleh, mengenai tingkat depresi pada lansia menunjukkan bahwa dari 60 orang responden hampir seluruhnya $43(71,7 \%)$ responden mengalami depresi dengan tingkat depresi berat. Hal ini dipengaruhi oleh beberapa faktor diantaranya kurangnya perhatian dari keluarga, banyak 
masalah, keluar dari kerjaan, selalu berfikir negative dan berputus asa, kekecewaan yang terlalu berlebihan.

Penelitian ini relevan dengan penelitian yang dilakukan oleh Dewi Kristyaningsih (2014) tentang hubungan antara dukungan keluarga dengan tingkat depresi lansia, hasil penelitiannya menyatakan terdapatnya hubungan antara dukungan keluarga dengan tingkat depresi pada lansia di Desa Langsar Laok Kecamatan Saranggi Kabupaten Sumenep.

Menurut Lubis (2009), secara sederhana depresi dapat dikatakan sebagai pengalaman yang menyakitkan, suatu perasaan tidak ada lagi harapan, yang ditandai dengan efek disforik (kehilangan kegembiraan) disertai dengan gejalagejala lain, seperti gangguan tidur dan menurunnya selera makan. Sedangkan Trisna (dalam Lubis, 2009) menyimpulkan bahwa depresi adalah suatu perasaan sendu dan sedih biasanya disertai diperlambatnya gerak dan fungsi tubuh.

Dari hasil analisa di atas didapat tingkatan depresi pada lansia yaitu depresi ringan, depresi sedang, dan depresi berat. Pada penelitian ini peneliti hanya menemukan dua tingkatan depresi pada lansia di Wilayah Kerja Puskesmas Kumun yaitu depresi tingkat berat dengan jumlah responden 43 dan depresi tingkat ringan dengan jumlah responden 17. Analisa peneliti bahwa tingakatan depresi yang terjadi pada lansia salah satu penyebabnya adalah kekecewaan yang dirasakan terlalu berlebihan dan kurangnya peran keluarga dalam merawat lansia sehingga membuat lansia menjadi stress yang berkelanjutan.

\section{Peran Keluarga dalam Merawat Lansia}

Berdasarkan data yang diperoleh dari penelitian mengenai peranan keluarga dalam merawat lansia diketahui bahwa dari 60 orang responden sebagian besar peran keluarga kurang baik dengan tingkat depresi berat sebanyak 33 responden $(55,0 \%)$

Penelitian ini relevan dengan penelitian yang dilakukan oleh Widiastuti (2009) tentang peran keluarga dalam merawat anggota keluarga yang sakit menderita stress akut atau depresi di wilayah kerja puskesmas Wirobrajan Yogyakarta tahun 
2009, hasil penelitian menyatakan bahwa sebagian besar responden mempunyai peran keluarga yang cukup baik.

Peran keluarga adalah sikap, tindakan dan penerimaan keluarga terhadap penderita yang sakit. Peran keluarga disebut juga tingkah laku spesifik yang diharapkan oleh seseorang dalam konteks keluarga. Sehingga peran keluarga menggambarkan seperangkat perilaku interpersonal, sifat, kegiatan yang berhubungan dengan individu dalam posisi dan situasi tertentu. Peranan individu dalam keluarga didasari oleh harapan dan pola perilaku dari keluarga, kelompok dan masyarakat.

Berdasarkan berbagai pernyataan diatas dapat dilihat bahwa peran keluarga sangat dibutuhkan dalam keadaan senang atau dalam keadaan sedih. Seseorang tidak akan menjadi seseorang yang benar tanpa ada campur tangan dari keluarganya. Jadi analisis peneliti dalam penelitian ini adalah semakin tinggi tingkat peranan keluarga dalam merawat lansia dengan tingkat depresi lansia semakin baik kondisi dari lansia tersebut.

\section{Hubungan antara Peran Keluarga dalam Merawat Lansia dengan Tingkat Depresi Lansia}

Berdasarkan hasil penelitian diperoleh data bahwa peran keluarga kurang baik dengan depresi tingkat berat sebanyak 29 (12,47\%) dan responden yang mengalami depresi tingkat ringan dengan peran keluarga kurang baik sebanyak 4 $(0,68 \%)$. Sedangkan pada peran keluarga baik dengan tingkat depresi berat sebanyak $14(6,02 \%)$ dan peran keluarga baik pada depresi tingkat ringan sebanyak $13(2,21 \%)$.

Untuk mengetahui hubungan antara peran keluarga dengan tingkatan depresi pada lansia menggunakan uji Spearman Rank yang menunjukkan nilai koefisien korelasi nilai Odd Ratio $(\mathrm{OR})=6,732$ dengan $\mathrm{P}$ value $=0.005$ dimana $\mathrm{p}<\alpha$ $(0,05)$ dengan arah korelasi negative, artinya semakin baik tingkatan peran keluarga maka kejadian depresi pada lansia semakin rendah. Sebaliknya semakin kurang tingkat peran keluarga maka semakin meningkat kejadian stress pada lansia. Berdasarkan hasil pengujian Spearman Rank menunjukkan bahwa peran 
keluarga dalam merawat lansia dengan tingkat depresi lansia di wilayah kerja Puskesmas Kumun mempunyai hubungan yang signifikan (bermakna).

Penelitian yang dilakukan oleh Ningrum (2011) tentang hubungan peran keluarga dengan pemenuhan kebutuhan perawatan diri pada lansia di Dusun Jogonalongan Lor Kasihan Bantul, hasil penelitiannya menyatakan terdapatnya hubungan antara peran keluarga dengan pemenuhan kebutuhan perawatan diri pada lansia di Dusun Jogonalongan Lor Kasihan Bantul.

Peran keluarga bukanlah salah satunya faktor yang mempengaruhi depresi pada lansia. Terdapat faktor-faktor lain yang berasal dari individu itu sendiri, misalnya selalu berfikiran negatif, emosi yang berlebihan, banyaknya tekanan sehingga terjadi kelelahan fisik dan factor yang berasal dari luar lansia yaitu perubahan lingkungan yang dapat mempengaruhi stress pada lansia (Azizah, 2011).

Asumsi penelitian berdasarkan analisa di atas perlunya peran keluarga dalam merawat lansia dengan depresi lansia karena dengan adanya perhatian, dorongan dan dukungan dari anggota keluarga lansia merasa tidak ditelantarkan yang membuat dia stress dan depresi.

\section{KESIMPULAN}

Berdasarkan hasil penelitian serta pembahasan penelitian yang berjudul Hubungan peran keluarga dalam merawat lansia dengan tingkat depresi lansia di wilayah kerja Puskesmas Kumun Tahun 2018. Diketahui bahwa kurang dari separoh peran keluarga kurang baik dalam merawat lansia dengan tingkat depresi lansia di Puskesmas Kumun, diketahui lebih dari separoh mengalami depresi dengan tingkat depresi berat di wilayah kerja Puskesmas Kumun. diketahui terdapatnya hubungan yang signifikan antara peran keluarga dengan tingkat depresi pada lansia di wilayah kerja Puskesmas Kumun.

Saran Bagi Dinas Kesehatan Kota sebagai pembuat kebijakan membuat anggaran yang jelas dalam pelaksanaan program jiwa di puskesmas, sehingga dokter spesialis jiwa dapat datang ke puskesmas secara rutin dan berupaya mendatangkan perawat spesilis jiwa. Untuk meningkatkan kemampuan petugas kesehatan yang ada dapat memberikan pelatihan seperti pelatihan $\mathrm{CMHN}$, sehingga program 
kesehatan jiwa berbasis komunitas dapat terlaksana. Sehingga diharapkan untuk Puskesmas Kumun lebih meningkatkan lagi pelayanan kesehatan dan fasilitasnya bagi pasien. Diharapkan pada penanggung jawab poli lansia agar dapat memberikan penyuluhan tentang kesehatan pada pasien lansia dengan depresi. Pendidikan ilmu keperawatan diharapkan mampu memamfaatkan hasil penelitian ini dalam pengembangan kurikulum pembelajaran keperawatan sebagai topik bahasan, baik dalam kelas maupun lahan praktek dimasyarakat secara lansung. Perawat spesialis jiwa dapat memamfaatkan hasil penelitian ini sebagai referensi untuk mengembangkan desain asuhan keperwatan jiwa pada konteks keluarga untuk mengoptimalkan terapi keluarga dalam meningkatkan dukungan keluarga dalam merawat anggota keluarga yang menderita depresi, sehingga perlu adanya penelitian lebih lanjut terkait dengan hubungan peran keluarga dalam merawat lansia dengan tingkat depresi lansia seperti dukungan masyarakat. Perlu adanya penelitian selanjutnya terkait dengan intervensi pada keluarga untuk meningkatkan peran keluarga pada lansia yang mengalami depresi guna menurunkan kekambuhan. 


\section{DAFTAR PUSTAKA}

Arikunto, Suharismi. (2009). Prosedur Penelitian. Jakarta : Rineka Cipta.

Depsos. (2006). Buku pedoman umum tim Pembina pengarah dan pelaksanaan kesehatan jiwa masyarakat Jakarta Depkes RI

Dewi. Kristyaningsih. (2014). Hubungan Antara Dukungan Keluarga Dengan Tingkat Depresi Lansia, Di Desa Langsar Laok Kecamatan Saranggi Kabupaten Sumenep. Jurnal Kesehatan diakses pada 13 Januari 2018

Efendi, Fery \& Makhfudli. (2009). Keperawatan Kesehatan Komonitas : Teori dan praktik dalam Keperawatan. Jakarta : Salemba Medika.

Friedman, Marilyn M., Bowden, V.R., \& Jones, F.G (2008). Buku Ajar Keperawatan Keluarga Riset, Teori Dan Praktik. Alih Bahasa, Achir Yani S. Hamid, dkk; Editor Edisi Bahasa Indonesia, Estu Tiar.-Ed. $3^{\text {th }}$ Jakarta: EGC.

Hastono. (2007). Analisa Data Keperawatan. Jakarta : Rineka Cipta

Hidayat, Aziz Alimul. (2008). Statistik Kesehatan. Jakarta : PT. Rajagrafindo Persada

Kristyaningsih, Dewi.(2011). Hubungan antara Dukungan Keluarga dengan tingkat depresi pada lansia. Jurnal Keperawatan. Dianhusada.ac.id/jurper1-10dew.pdf. Diakses pada tanggal 25 januari 2018.

Lubis. B. A. (2009). Catatan Ilmu Kedokteran Jiwa. Surabaya. Airlangga University Pres

Munthe. (2007). Essensial of Psychiatric Mental Healt Nursing. $4^{\text {th }}$ ed. Philadelphia: F.A Davis Company

Nevis, Ruthus dkk.(2005). Gejala Depresi dan Penyebab Depresi. Journal Kesehatan Keluarga. (Diakses pada tanggal 12 Januari 2015 jam 20.00).

Ningrum. (2011). Hubungan Peran Keluarga Dengan Pemenuhan Kebutuhan Perawatan Diri Pada Lansia di Dusun Jogonalongan Lor Kasihan Bantul. Jurnal Kesehatan di akses pada 3 Februari 2015

Nisa", Kamilatin. (2014). Dukungan Keluarga Dengan Tingkat Depresi Pada Lansia Di Desa Gayaman Kecamatan Mojoanyar Kab. Mojokerto. http://repository.poltekkesmajapahit.ac.id. Diakses pada tanggal 16 Januari 2015.

Notoatmodjo, Soekidjo. (2012). Ilmu Kesehatan Masarakat Prinsip-Prinsip Dasar. Jakarta : Rineka Cipta 
Notoatmodjo, Soekidjo. (2010). Metodologi Penelitian Kesehatan. Jakarta : Rineka Cipta.

Nursalam. (2008). Konsep dan penerapan Meteologi Penelitian Ilmu Keperawatan. Jakarta : Salemba Medika

Setyawati, Sri \& Murwani, Arita. (2008). Asuhan Keperawatan Keluarga. Konsep dan Aplikasi Kasus. Jogjakarta: Mitra Candika.

Sugiyono. (2012). Metode Penelitian Kuantitatif dan R\&D. Bandung : Alfabeta

Sugiyono. (2013). Metodologi Penelitian. Bandung : Alfabeta

Sujarweni, V. Wiratna. (2014). Metodologi Penelitian Keperawatan. Yogyakarta : Gava Media.

WHO (2009). The Word Health Repoth: 2013: Mental Health: New Understanding. New Hope. www.who.Intek/2013/0n. Diakses pada Januari 2018.

Widiastuti. (2009). Peran Keluarga Dalam Merawat Anggota Keluara Yang Sakit Menderita Stress Akut Atau Depresi Di Wilayah Kerja Puskesmas Wirobrajan Yogyakarta. Jurnal Kesehatan diakses pada 13 Januari 2018. 